\title{
DEBT FINANCING AND FINANCIAL PERFORMANCE OF SMALL AND MEDIUM SIZE ENTERPRISES: EVIDENCE FROM KENYA
}

\section{DOI: 10.17261/Pressacademia.2015312967}

\author{
Peter Nderitu Githaiga', Charles Githinji Kabiru² \\ ${ }^{1}$ Moi University. nderitugithaiga@mu.ac.ke \\ ${ }^{2}$ Moi University. charleskabiru88@yahoo.co.uk
}

\section{Keywords}

Debt financing, long term debt, short term debt, trade credit, SMEs.

\begin{abstract}
Debt ratios in large firms have been examined by a number of researchers while smaller firms have attracted less attention. The financial policies of large listed companies often differ from smaller firms because they raise funds by issuing debt or equity into capital markets. As such this study sought to investigate the effects of debt financing on the financial performance of SMEs. The objectives of the study were to determine the effects of long-term loans and short-term loans on SMEs financial performance. The study was guided by optimal capital structure theories. The study target 4122 SMEs in Eldoret town. Stratified sampling technique was used to select a sample size of 50 SME firms in Eldoret Town. The study collected quantitative secondary data from SMEs' financial statements for three consecutive years (2011-2013). The reliability and validity of the data collection instrument was done using Cronbach Alpha. Multiple Regression analysis was used to test study hypothesis. The results revealed that short term loans $\beta=-0.304$, and long term loans $\beta=-0.155$ had negative impact on financial performance of SMEs. The study concluded that long term and short term loans reduce financial performance of SMEs. The study recommends that SME should utilize loans, diversify for sustainability of revenue, keep proper books of accounts, offer clients sales contracts and lay down payment modes for trade credits, clearly stipulate the payment schedules, in order to deter poor credit and loan control policies and train their staff regularly while employing experienced internal and external auditors to improve on the internal control systems and book keeping.
\end{abstract}

\section{JEL Classification G11,G21,G30}

\section{INTRODUCTION}

Small and medium-sized enterprises are a centerpiece of the world economy. This includes most developed economies such as Europe economy. This is due to their economies of scale and their financing operations and, in particular, from access to securitized lending and stock markets. However, SME limitations in financing their operations may seriously limit their expansion potential and, in particular when it comes to lack of risk capital and their innovation (Akhtar, 2005). 
Although in recent decades, small and mid-sized enterprises (SMEs) have been shown to be the primary engines of economic performance (Acs and Audrestsch, 2001), few large scale studies of SMEs actually document the role that external capital plays in the overall financing and performance of these businesses (Brown et al,2010). Debt financing involves the procurement of interest bearing instruments. They are secured by asset-based collateral and have term structures, that is, either short or long term. The equity component of external finance gives the financier the right of ownership in the business and as such may not require collateral since the equity participant will be part of the management of the business (Ogujiuba, Ohuche, and Adenuga, 2004). Pindalo, Rodrigues and de la Torre (2006) argue that short-term debt is not affected by the trade off between tax benefits and bankruptcy costs and that long-term debt is affected by collateralisable assets but short-term debt is not.

In Kenya, the performance of SMEs has continued to decline over the years. As at (Gok, 2009) virtually most small enterprises had collapsed leading to the closure of some of the SMEs that were producing $40 \%$ of the employment in Kenya. Other SMEs were auctioned while some were merged or acquired signifying questionable financial performance. Between 2001 and 2002, the SMEs performance dropped by 56\% (Kenya Economic Survey, 2003). On the other hand, industrial economists indicated that the small industries have higher bankruptcy rates and also a faster growing rate than larger industries. SMEs still experience various difficulties in improving their financial performance since short term loan, trade credit and long term loans are not well managed. This may be as a result of SMEs not using ideal debts in their day-to-day transactions and if this problem is not tackled it may continue to cause financial distress and business failure.

Nevertheless, the abundance of loan facilities plus the demanding approval requirement of the scantily available equity funds has led many of the SMEs to resort to debt. This phenomenon is theoretically and practically acceptable from the loan providers' perspective owing to the perceived high risk of moral hazard problems among small and medium enterprises. While debt is necessary for the free flow of cash in the operation of the SMEs, over proportion of debt in their financial structure may pose problem to their financial health and performance.

Previous studies pertaining to the relationship between finance and performance had so far been focused on larger firms. Yet, very little attention is given to the actual forms of finance used by small and medium-sized enterprises, the available finance made by lending institutions or investors and the relation between the use of the said debt finance and enterprise performance. Thus, the study was conducted to examine effects of debt financing on financial performance of SMEs.

Focusing on the SMEs debt financing, this paper emphasizes the importance of debt structure (that is long-term, short-term debt and trade credit) in financing SMEs. In fact, we argue that SMEs should focus only on trade credit in order to optimize their financial performance. 


\section{LITERATURE SURVEY}

SME Financial performance is most often defined into hard criteria such as increased turnover or wider profit margins and the ability to contribute to job and wealth creation through business start up, survival and growth (Sandberg et al, 2002, Chell \& Baines, 1998).

Financial performance can be measured using proxies like profitability, return on asset, liquidity, solvency, and sales growth and all these can be extracted from the financial statements and/or reports (Dobbins and Barnard, 2000).

Debt financing is the major sources of capital for truly nascent firms since the retained earnings are insufficient or not available (Robb and Robinson, 2008as cited in Sun, 2010). According to Sun (2010), SMEs depend on debt financing because debt financing is relatively cheaper compared to equity financing (Graham, 2000). In addition, firms have insufficient track records, resulting in a relatively higher risk for capital suppliers (Berger and Udell, 1998). Therefore, shareholders are less likely to provide money for such firms.

Many smaller, less liquid firms do not enjoy access to debt markets but nevertheless can acquire external funds through bank lending, loans from associated firms, trade credit and other means. In structuring their liabilities, firm managers must choose their associated maturity, taking into account many of the same issues and constraints that affect the choice of a debt maturity structure (Baum et al, 2007)

Dobbins, Barnard (2000) The forgoing review of the literature on SMEs financing suggests that, until now, no tool has been provided to deal with capital structure in general and debt maturity in particular: theoretical models do not accommodate the special characteristics of SMEs; empirical research has provided only ex post explanation rather than specifying how an optimal capital structure may be determined. As far as we are able to ascertain from the existing finance literature, no practical tool has been elaborated for enabling SMEs to optimise their capital structure.

\section{Long Term Debts and Financial Performance}

Long-term debt limits managerial discretion by making access to new funds and overinvestment less likely Hart and Moore (1995): a feature that would enhance profitability. Schiantarelli and Jaramillo (1996) argue that shorter-term loans are not conducive to greater productivity while long-term loans may lead to improvements in productivity (Schiantarelli and Srivastava (1996)

It is higher in stronger and more flexible firms, when there are big differences between short term and long term interest rates and when firms have more growth opportunities (Moro, 2009). An econometric study by Hernandez-Canovas and Koeter-Kant (2008), suggests that the important variables in determining SMEs long-term debt include the length of the banking relationship and the number of banks involved (cited in Moro, 2009)

$H_{O 1}$ : Long term debts had no significant effect on the financial performance of SME

\section{Short-Term Debt and Financial Performance}


Short-term debt in an environment of incomplete contracts grants the lender a control right as the firm's ability to roll over the debt may be conditioned on financial ratios and adequate performance. As this mechanism limits managerial discretion it may contribute to the relaxation of financial constraints (Rajan and Winton (1995). This increased availability of external finance should stimulate better performance.

Maturity matching between debt and the life of assets plays an important role in deciding the length of the debt maturity (Ooghe, 2007). According to Garcia-Terul and MartinezSolano, (2007) Short-term debt is positively correlated with firm's growth opportunities. short-term debt is the best financing tool because it is perceived to be cheaper. Thus, both entrepreneur and bank prefer short-term debt (Landier and Thesmar, 2009)

\section{$H_{O 2}$ : Short term debts had no significant effect on the financial performance of SME}

Recent literature on SMEs debt financing suggests that, until now, no tool has been provided to deal with debts in general and it's effect on SMEs' financial performance: theories have not fully accommodated the capital structure of SMEs; in addition, empirical research has not specified on how an optimal capital structure may be determined. As far as we are able to ascertain from the existing finance literature, no practical tool has been elaborated for enabling SMEs to determine the best debt financing that will suit their financial performance.

\section{DATA AND METHODOLOGY}

The researcher employed a descriptive and explanatory research design. This study was carried out in Eldoret town. The town is among the fastest growing towns in Kenya. The town is located in North Rift, Uasin Gishu County, Kenya.The study population was composed of 4122 SMEs in Eldoret town whose capital structure comprised of debt financing as reflected in their financial statements (External Audits Database, 2013). The Nassium sample size formula was used, taking the standard error, the coefficient of variation and the population into consideration in determining sample size (Nassium, 2000). Using Nassium formula at 2.8 percent standard error and $21 \%$ coefficient of variation the sample size for SMEs was 50 . Data was collected from financial reports for the last three consecutive years from 2008-2010 through use of documentary guide. Hence, observations of 3 years for each of the 50 SMEs $(3 * 50=150)$ were regarded as the study sample size.

Table 1: Measurement of Variables

\begin{tabular}{|l|l|}
\hline Variables & Measurement \\
\hline Long term debts ratio & Long term loan/total loan \\
\hline short term debt ratio & Short term loan/total loan \\
\hline Profit Margin Ratio & Gross profit/sales \\
\hline
\end{tabular}




\begin{tabular}{|l|l|}
\hline Return on Assets & $\begin{array}{l}\text { Net Income/total assets (Michaelas, Chittenden, and } \\
\text { Panikkos, 1999) }\end{array}$ \\
\hline Current ratio & Current assets/current liabilities \\
\hline
\end{tabular}

Pearson correlation coefficient was used to determine the degree of relationship between long-term loan, trade credits, short term loan and financial performance. Multiple regression analysis was used to predict the financial performance of SMEs.

These regression equations are outlined below.

$$
y_{i}=\beta_{1}+\beta_{1} x_{1}+\beta_{2} x_{2}+\varepsilon
$$

Yi $(\mathrm{i}=1 \ldots . . .3)=$ Profit Margin ratio, Liquidity and Return on Asset

$\mathrm{X}_{1}=$ Short Term debt

$\mathrm{X}_{2}=$ Long term debt

$\varepsilon=$ error term.

\section{EMPIRICAL FINDINGS}

Means and standard deviations for all the variables were calculated in order to get an idea about the direction of all the variables (profit margin ratio, liquidity ratio, return on asset,trade credit, long term debt ratio and short term debt ratio.

Table 2: Descriptive Statistics

\begin{tabular}{lllllcc}
\hline & Min & Max & Mean & Deviation & Skewness & Kurtosis \\
\hline Profit Margin Ratio & 0 & 3.62 & 0.6107 & 0.24898 & -0.741 & 0.105 \\
Liquidity Ratio & 0 & 3.24 & 0.5881 & 0.12115 & 0.981 & 0.075 \\
Return On Asset & 0 & 2.64 & 0.5023 & 0.26888 & 0.803 & 0.196 \\
Long Term Debt Ratio & 0 & 2.62 & 0.3935 & 0.22536 & -0.813 & 0.41 \\
Short Term Debt Ratio & 0.02 & 0.93 & 0.5226 & 0.33017 & 0.944 & 0.269 \\
Performance & 0 & 4.34 & 0.7283 & 0.22391 & 0.231 & 0.330 \\
\hline
\end{tabular}

Table 2 reveals that profit margin (PMR) score was averaged $0.61 \%$, liquidity ratio at $0.58 \%$, ROA at $0.50 \%$. Further, results indicated that there are average $39 \%$ and $52.26 \%$ Long-term and short term loans among SMEs respectively. Moreover, all standard deviation values are below the means values reflecting a small coefficient of variation. The range of variation between maximum and minimum is also reasonable. 
Table 3: Correlations Analysis

\begin{tabular}{|c|c|c|c|c|c|}
\hline & $\begin{array}{l}\text { Profit margin } \\
\text { ratio }\end{array}$ & $\begin{array}{l}\text { Liquidity } \\
\text { ratio }\end{array}$ & $\begin{array}{l}\text { Return } \\
\text { on asset }\end{array}$ & $\begin{array}{l}\text { Long term } \\
\text { debt ratio }\end{array}$ & $\begin{array}{c}\text { Short term debt } \\
\text { ratio }\end{array}$ \\
\hline Profit Margin Ratio & 1 & & & & \\
\hline Liquidity Ratio & $.329 * *$ & 1 & & & \\
\hline Return On Asset & $.281^{* *}$ & 0.038 & 1 & & \\
\hline Long Term Debt Ratio & 0.061 & $-0.102 *$ & -0.033 & 1 & \\
\hline Short Term Debt Ratio & $-.478 * *$ & $-.373 * *$ & $-.351 * *$ & -0.123 & 1 \\
\hline
\end{tabular}

Long term debt was reported to have significant and negative relationship with liquidity ratio $(r=-0.102$, value $<0.05$ ), this results reported that long term debts had negative influence on performance and liquidity ratio, however, there was no evidence to suggest relationship between long term debts, ROA and profit margin ratio.

Short term debt ratio was negatively and significantly correlated to profit margin ratio $(r=$ $-0.478 p$ value $<0.01)$, liquidity ratio $(r=-0.373, p$ value $<0.01)$ and return on asset $(r=-$ $0.351, p$ value $<0.01$ ). These results suggest that long term and short- term loans in SMEs negatively affect the performance of the SMEs.

Table 4: Regression Results

\begin{tabular}{|c|c|c|c|c|c|c|}
\hline & \multicolumn{2}{|c|}{$\begin{array}{l}\text { Model 1, } \\
\text { Dependent Variable: } \\
\text { Profit Margin Ratio }\end{array}$} & \multicolumn{2}{|c|}{$\begin{array}{l}\text { Model 2, } \\
\text { Dependent Variable: } \\
\text { Liquidity Ratio }\end{array}$} & \multicolumn{2}{|c|}{$\begin{array}{l}\text { Model 3, } \\
\text { Dependent Variable: } \\
\text { Return on Asset }\end{array}$} \\
\hline & Beta & $\mathbf{t}$ & Beta & $t$ & Beta & $\mathbf{t}$ \\
\hline Long Term Debt Ratio & -0.003 & -0.037 & $-0.155^{*}$ & -2.092 & -0.08 & -1.043 \\
\hline Short Term Debt Ratio & -0.94 & -6.595 & $-0.384^{*}$ & -5.176 & $-0.356^{*}$ & -4.625 \\
\hline ANOVA (F ratio) & 17.539 & & 0.21 & & 0.27 & \\
\hline ANOVA (Prob) & 0 & & 0.194 & & 0.261 & \\
\hline R Square & 0.265 & & 12.92 & & 8.408 & \\
\hline Adjusted R Square & 0.25 & & $.000 a$ & & 0 & \\
\hline
\end{tabular}

Dependent Variable: Profit margin ratio ,: Liquidity ratio,: return on asses

From table 4 we had enough evidence that Long term debt affect liquidity negatively ( $\beta=$ $0.155, p<0.05)$, hence the study reject null hypothesis long term debt has no significant effect on SME financial performance (liquidity ratio ), we therefore suggest that an increase of long term debts in SMEs will lower SMEs performance through liquidity. More 
findings indicated short term debts having a negative effect on both liquidity and return on asset $(\beta=-0.384, p<0.05$ and $\beta=-0.356, p<0.05$ respectively). We therefore reject hypothesis that short term debts have no effect on SMEs financial performance (ROA and liquidity). Increase of short term debts reduces ROA and SMEs liquidity.

\section{CONCLUSION}

Empirical results showed enough evidence that long term debts affect SMEs financial performance negatively. These results are contrary to Schiantarelli and Jaramillo (1996) argument that long-term loans may lead to improvements in productivity. The findings further disagrees with Moore (1995) argument that Long-term debt limits managerial discretion by making access to new funds and over-investment less likely: a feature that would enhance profitability.

Similarly, findings showed that short term debts negatively affects SMEs performance through ROA and liquidity, the study findings contradicts Garcia-Terul and MartinezSolano (2007) that short-term debt is positively correlated with firm's growth opportunities. Short-term debt is not the best financing tool for SMEs.

Thus, both short term and long term loan affect SMEs financial performance negatively. Caprio et al (1997), opines that long term debt dampens the firm's response to deterioration in market conditions, and enables the firms to avoid exiting the market when the continued operation of the firm has become socially undesirable ( cited in Tanko,2002). Brunila (1992) asserted that credit regulations of banks have major influence on SMEs' operations, because they cannot get financing from bond markets, stock markets or abroad as effortlessly as large and stable corporations.

The study findings suggest both long term and short term loans reduce the financial performance. This calls for capacity building of SMEs in areas of business management (including financial record keeping) if they are to be rated as need to improve on their financial performance, thus they should reflect in reduction of loan processing time and the cost of borrowing (i.e. interest rates).Given the above, it could be suggested that Government will gain a lot from promoting SMEs through training and skill acquisition that will enable them better utilize their loans thereby reducing the probability of their being credit rationed. This becomes even more important for Kenya given the level of unemployment and government efforts in terms of policy frameworks that the Government has put in place to address them.

One of the feasible options open to SMEs in Kenya is the formation of cooperative societies where there will be a kind of risk pooling when applying for bank loans. Indeed, banks are likely to be more comfortable dealing with groups than individual SMEs who may not have relevant experience and financial skills to convince banks to part with liquidity in form of loans. Hence, SMEs in Kenya are likely to benefit more from commercial bank loans if they work with themselves as a group rather than doing it all alone. We must bear in mind that the most important goal of commercial banks is profit making. For best results, financial statements and other key performance indicators should be prepared on a regular and consistent basis and compared with prior periods. 
Monitoring performance using successive monthly or quarterly accounts can show trends that otherwise might not be apparent

Further research could test the issues raised in this study across a large representative sample of SMEs. It is very important to monitor a wide range of performance indicators in the SMEs in order to ensure that appropriate and timely decisions and plans can be made. Given that profit margin ratios, current asset ratios and Return on Asset are the lifeblood of SMEs.

More frequent reporting periods are needed for more important data as well as use of other financial and non-financial indicators. Examples are number of enquiries, number of customers per day, average sales value, number of quoted jobs lost, and customer satisfaction.

\section{REFERENCES}

Acs, Zoltan and David Audretsch, (2001). The Emergence of the Entrepreneurial Society, Presentation for the Acceptance of the 2001 International Award for Entrepreneurship and Small Business Research, Stockholm, May, 2001.

Akhtar, S. (2005). The determinants of debt financing for Australian multinational and domestic corporations. Australian Journal of Management, 30(2), 321

Baum.C.F, Schafer.D, and Talavera.D.,(2007), The Effects of Short-Term Liabilities on Profitability: A Comparison of German and US Firms, DIW Berlin, K"onigin-Luise-Str

Berger, A. and Udell, G. (1998) 'The economics of small business finance: The roles of private equity and debt markets in the financial growth cycle', Journal of Banking \& Finance vol. 22, 613-73.

Caprio, G. \& Demirgue-Kunt, K. 1997. The Role of long term finance: theory and Evidence. Washington D.C . World Bank

Chell, Elisabeth- Baines, Susan (1998) Does Gender affect business "performance"? A study of micro-businesses in business services in the UK. Entrepreneurship \& Regional Development, 10, p.117-135.

Fama, E. F., K. R. French, (2002), 'Testing Trade-Off and Pecking Order Predictions about Dividends and Debt', The Review of Financial Studies Vol. 15 No. 1, pp. 1-33.

García-Teruel. P. J., And Solano P.M., (2007), Trade Credit and SME Profitability, International Small Business

GOK, G. o. (2009). Economic Survey. Nairobi: Government Printer.

Graham, J. R. (2000). How big are the tax benefits of debt? Journal of Finance, 55(5), 1901-1941.

Gregory W. Brown.G.W., Chavis.L.W., and Klapper.L.F.,2010, A New Lease on Life: Institutions, External Financing, and GrowthAmerican.Finance Association

Hart, O., and J. Moore. 1995. "Debt and Seniority: An Analysis of the Role of Hard Claims in Constraining Management." American Economic Review (June): 567-585.

Hernandez-Canovas, G., J. Koëter-Kant, (2008), “Debt Maturity and Relationship lending”, International Small Business Journal, 26, 5, 595-615 
Jaramillo, F., F. Schiantarelli and A. Weiss, (1996). "Capital Market Imperfections Before an After Financial Liberalization: An Euler Equation Approach To Panel Data for Ecuadorian Firms." Country Economics Department Working Paper 1091. Washington, DC, United States: World Bank.

Landier, A., D. Thesmar, (2009), "Financial Contracting with Optimistic Entrepreneurs", The Review of Financial Studies, 22, 1, 117-150

Miwa, Y., J. M. Ramseyer, (2008), "The Implications of Trade Credit for Bank Monitoring: Suggestive Evidence from Japan", Journal of Economics and Management Strategy, 17, 2, 317-343

Moro, Andrea; Lucas, Michael; Bazzanella, Claudio and Grassi, Edo (2009). The short term debt vs. long term debt puzzle: a model for the optimal mix. In: 5th Conference on Performance Measurement and Management Control, 23-25 September 2009, Nice, France.

Pindalo, J., L. Rodrigues, C. de la Torre,(2006), “How Does Financial Distress Affect Small Firms' Financial Structure?", Small Business Economics, 26, 377-391

Rajan, R. G. and Winton, A. (1995), 'Debt covenants, collateral, and delegated monitoring', Journal of Finance 50(5), 1113-46.

Robb, A., \& Robinson, D. T. (2008). The capital structure decisions of new firms: Second in a series of reports using data from the Kauffman Firm Survey. Available at SSRN: http://ssrn.com/abstract=1292552

Sandberg, K.- Vinberg, S. - Pan, Y. (2002) An exploratory study of women in micro enterprise; owner perceptions of economic policy in a rural municipality: Gender-related differences. In: CD- proceedings of 12th Nordic Conference on Small Business Research. Creating Welfare and Prosperity through Entrepreneurship. Kuopio Finland May 26-28, 2002. p. 114.

Tanko, (2002), the Effect of Restructuring on the Financing Pattern of Development Banks in Nigerian International Review of Business Research Papers Volume 6. Number 4. September 2010. Pp. 157-167 